\title{
ORGANISATION'S COMMUNICATION ACTIVITY AND THE LEVEL OF PROCESS MATURITY - AN EMPIRICAL APPROACH
}

\author{
Barbara BIELICKA ${ }^{1}$, Agnieszka GOŹDZIEWSKA-NOWICKA ${ }^{2 *}$, Tomasz JANICKI ${ }^{3}$ \\ ${ }^{1}$ WSB University in Toruń, Toruń; barbara.bielecka@wsb.torun.pl, ORCID: 0000-0003-2978-8893 \\ ${ }^{2}$ Bydgoszcz University of Technology, Bydgoszcz; agnieszka.gozdziewska@pbs.edu.pl, \\ ORCID: 0000-0001-5949-3901 \\ ${ }^{3}$ WSB University in Toruń, Toruń; tomasz.janicki@wsb.torun.pl, ORCID: 0000-0002-7717-2201 \\ * Correspondence author
}

Purpose: The authors aimed to identify the characteristics of a process organisation, and to determine the organisation's activity in various areas, including communication.

Design/methodology/approach: The research methods used in the article was an online survey.

Findings: The conducted research is the first step in assessing the relations that occur between the level of process maturity of an organisation and the level of communication activity. In the surveyed organisations there is a high awareness of the need and importance of processes. Research limitations/implications: The study of corporate image and the study of reputation and prestige in the area of internal communication activity. A group of about $64 \%$ of organisations declared such activity, although to varying degrees. About $33 \%$ of respondents declared these activities as strategic. It should be assumed that they are the result of image activities, activities focused on reputation and prestige. It can be assumed that these are activities of public relations or corporate communication. Admittedly, further research reveals the lack of certain processes, which are important and determine the strategic character of these activities (e.g., lack of CSR, lack of employer branding).

Practical implications: Achieving more and more process maturity through process improvement should be treated as a cyclical activity, which is oriented towards the continuous search for better solutions. Organisations that intend to improve their processes, and thus gain greater process maturity, should continually take care to shape open communication, both within the company and in the external environment.

Originality/value: Strategic achievement of an integrated state of internal and external communication is based on constructive dialogue and is determined by the number of different processes, the level of communication and the level of their process maturity.

Keywords: process maturity, stakeholder relations management, communication system.

Category of the paper: research paper. 


\section{Introduction}

Nowadays, one of the most important concepts in the field of management and organisation is the process approach, which requires organisations to be active in many fields of activity. The functioning of contemporary organisations in competitive markets takes various forms. The triggering factor for different types of activity is market presence, staying in the market, and often developing a market position.

Companies exhibit different behaviours, ranging from evolutionary change models to planned change models. At present, it is more common to see companies planning their future market position, company development, or future success.

Planning for the future success of an organisation requires a holistic approach to the entirety of activities, which include many events in the internal and external environment of the organisation. This includes the multidimensional perception and definition of tasks and the organisation of work in many new sections in the organisation, where it has not operated before and yet maintained its position in the market. This requires organisations to apply multidimensional, multi-use and multi-objective processes, running through different routes and channels in the organisation. Not all organisations implement such changes, because such changes are not possible in all entities. These changes require certain specific conditions. However, the basis for the introduction of any modification in an organisation is information, the way it is acquired, processed, transmitted, the ability to send, receive, encode and decode it. These are all phenomena, tasks and activities that make up the processes of external and internal communication of the organisation.

One of the important factors determining the process maturity of an organisation and its levels is efficient communication in the organisation. Informing and communicating is the starting point of organisational development. Communication in an organisation is its foundation, the basis of marketization of inter-organisational relations (Grajewski, 2003, p. 127). There is no doubt that good information and communication in an organisation is the foundation on which organisations can develop their process maturity.

Good communication is considered to comprise processes which serve to 'create value' for the customer. This means that information and communication in a process organisation should strive to build relationships with internal and external customers, based on which networks of internal relationships and communication are created.

One of the most important issues is the activity of the organisation in communication processes, especially the way in which enterprises with a process orientation and a certain degree of process maturity operate. 
Process orientation is undoubtedly an important and current topic, hence the research team decided to focus on this issue. At the turn of 2018 and 2019, a survey was carried out that covered 240 organisations. An online survey was used as the method of measurement. A total of 152 micro organisations (with 1 up to 9 employees), 43 small organisations (with 10 up to 49 employees), 16 medium-sized organisations (with 50 up to 249 employees) and 29 large entities (with more than 250 employees) were surveyed. As many as 199 entities provided primarily services, the others were mainly involved in the manufacture of goods. Most organisations (212) are domestic entities - without foreign capital. The respondents were people responsible for implementing processes, including process owners, project managers and process management specialists. The aim of the research project was to provide answers to the following questions: 'Does process orientation require special communication skills and competences from organisations?', 'Does the organisation's process maturity in communication constitute one of many maturity levels?' and 'Does it constitute the basis, the foundation for process maturity in other areas?'

In the first research part, the authors aimed to identify the characteristics of a process organisation, while in the second part they aimed to determine the organisation's activity in various areas, including communication, especially in the areas of building internal relations as well as in the areas of building external relations of the organisation.

\section{Customer value as a result of process maturity}

Value for the client, i.e., the surplus of certain subjective benefits over costs, should not only be acceptable to the client, but also co-created by him. The client is increasingly taking the role of a prosumer and a proclient. This means that the organization's internal communication and information network has the ability to create internal relations with the client, which in fact serve the development of communication processes with stakeholders, not only internal, but primarily external. Organizations build various structures for external stakeholders. One of them are customers, media, suppliers, recipients, social and political environments, as well as hostile environments of the organization.

The contemporary customer accepts the value offered by the organisation, as he himself participates in its creation, through his participation, activity and involvement in market communication processes. However, it is in the interest of the organisation to strive to be present, not only in the market environment, but in the entire social communication system. This presence manifests itself through activity in CSR, public, and political areas. On the one hand, the organisation uses the system, and on the other hand, however, it is the creator of this social communication system. It aims at gaining, accepting and advocating not only customers, but also other participants of different audiences that are part of the social communication 
system (Kotler, 2017, pp. 75-79). The customer value is thus reinforced, confirmed by other social environments (e.g., media).

Customer value is also the result of conscious, planned, continuously controlled efforts to build a corporate brand, which is a holistic, multidimensional view of one's own company.

A corporate brand refers to both external and internal stakeholders. These are employees, customers, suppliers, intermediaries, business partners, shareholders, society (Daszkiewicz, Wrona, 2014, pp. 28-29). The processes that build a corporate brand include:

- the process of creating a product/brand image,

- the process of creating a relationship with the client,

- the process of creating relations with the media,

- the process of creating internal media relations,

- the process of creating external media relations,

- communication process in crisis situations,

- employer's branding process;

- internal employer branding - for employees,

- external employer branding - for future employees,

- CSR (Corporate Social Responsibility).

Communication processes covering the above-mentioned areas, aimed at the entire society, focused on the value that unites all brands and allows them to speak as one to the client are known as Public Relations. Public Relations activities as a function of strategic organization/enterprise management are aimed at creating value for the recipient. There is a close correlation between the concept of Public Relations activities and the concept of corporate communication (Kuraszko, 2010, p. 26).

\section{Public relations as an organization's social communication system}

Tables, figures and formulas - continuous numbering in the text. As Krystyna Wojcik states: Public relations is a systematic and process-oriented activity - a system of activities within the scope of social communication, a social process of a constructive, reliable dialogue, (...). It is a conscious, purposeful/intentional, ethical activity - based on truth, consistency of words and deeds, openness in information and communication, partner treatment of the environment, responsibility towards it (Wojcik, 2015, p. 26).

Is an activity aimed at shaping the image/reputation and desired relationships between the organisation undertaking the activity (...) and those groups in its environment who feel affected by the actual and potential effects of its strategy (Wojcik, 2015, p. 26). 
Public Relations is a methodical, planned, systematic activity based on research and analysis, social monitoring, management of communication in an organisation, participation in problem and strategic management, advising decision-makers in an organisation and influencing them to create desired situations, phenomena and structures in an organisation, as well as a culture oriented towards communities, society, environment, in a short-term and long-term perspective, using the achievements of all those sciences that create opportunities for effectiveness (Wojcik, 2015, p. 26).

Public relations is an activity that is permanent and long-term in the case of programmes aimed at corporate image, and limited in time in the case of (...) current programmes (Wojcik, 2015, p. 26).

The system of communication of mutual relations defined by Wojcik is based on informing, listening, communicating, taking into account the arguments of many groups on which the organisation depends and on dialogue. Dialogue is a basic communicative act occurring in conversation and then implemented in teams, processes, and in the system.

It is therefore worth considering how to create a social communication system for the organisation, where there are many social groups of different sizes, both inside and outside the organisation, so that it is based on dialogue. The strategic stakeholder management model presented in Figure 1 illustrates the importance of symmetrical two-way communication between an organisation's stakeholders and the need to gain legitimacy from market and nonmarket stakeholder groups (Cornelissen, 2012, p. 58).

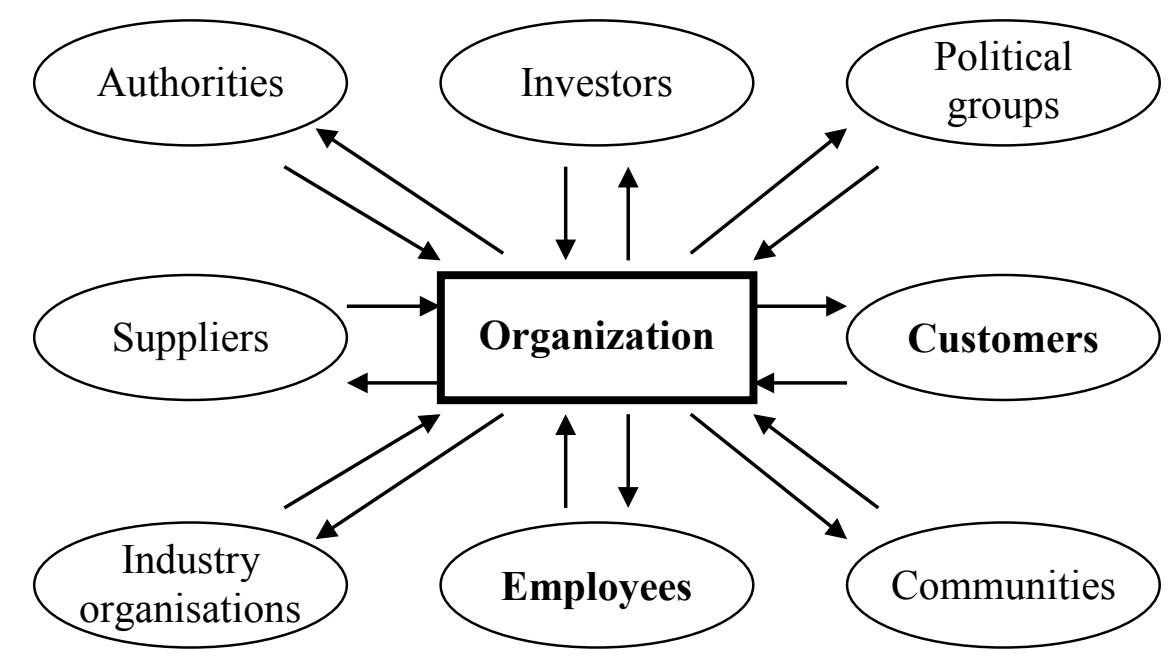

Figure 1. A stakeholder-driven strategic management model. Adapted from: "Komunikacja korporacyjna. Przewodnik po teorii i praktyce" by J. Cornelissen. Copyright 2012 by Publisher Oficyna a Woltares Kluwer business.

In the context of the above considerations, it is worth considering to what extent the surveyed organisations are prepared to undertake communication activities with stakeholders based on bilateral symmetrical communication with dialogue dominating. 


\section{Communication activity of the surveyed organisations}

Internal communication is an extremely important element of every organisation. Modern companies are aware of the importance of communication with employees, which is why they aim to use communication tools effectively, not only to inform, but also to convey emotions and prepare for the implementation of organisational changes. A very important function of internal communication is to integrate employees around the company's strategy and at the same time create an organisational culture based on honesty and trust. Moreover, internal communication activities influence the relationship between employees and management, which shapes the company's image both internally and externally.

In the area of internal communication, most of the surveyed organisations declared that they undertake activities such as reputation and prestige research (65.82\% of respondents), corporate image research $(64.15 \%$ of respondents). However, $1 / 4$ of respondents $(24 \%)$ consider these activities as important $(9.6 \%)$ and very important $(13.3 \%)$ of operational significance. These results may indicate the involvement of the surveyed organisations in communication with an image profile (24.16\%), corporate image research and $22.91 \%$ reputation and prestige research. There is no doubt that taking care of quality and reputation is as important as maintaining the high quality of products offered and services provided. Moreover, these activities can be a premise for the conclusion that these organisations are planning for future image success, the state of communication of these organisations is the beginning of internal image communication. The literature refers to such activities as internal relations. They form the foundation for strategic public relations activities.

About $35 \%$ of the respondents $(35.41 \%)$ confirm that public relations activities are carried out at the strategic level of the organisation, half of them $(17.5 \%)$ consider them to be very important of strategic importance and the same number (17.91\%) consider them important of strategic importance. Detailed results of the internal communication activities of the surveyed organisations are presented in Table 1.

The below results correlate with the assessment of activities in the area of internal employer branding, i.e., the concentration of activities in communicating internal stakeholders in order to create a brand value associated with the employee. And this, as a consequence, creates the image of a good employer. About $1 / 5$ of the respondents $(21.24 \%)$ consider these activities as strategically important $(12.9 \%)$ and very important $(8.3 \%)$. 
Table 1.

Internal communication activity

\begin{tabular}{|l|c|c|c|c|c|}
\hline $\begin{array}{c}\text { Internal } \\
\text { communication } \\
\text { activities }\end{array}$ & $\begin{array}{c}\text { Very } \\
\text { important of } \\
\text { strategic } \\
\text { importance } \\
\text { in \% }\end{array}$ & $\begin{array}{c}\text { Important of } \\
\text { strategic } \\
\text { importance } \\
\text { in \% }\end{array}$ & $\begin{array}{c}\text { Very } \\
\text { important of } \\
\text { operational } \\
\text { significance } \\
\text { in \% }\end{array}$ & $\begin{array}{c}\text { Important of } \\
\text { operational } \\
\text { significance } \\
\text { in \% }\end{array}$ & $\begin{array}{c}\text { Very important } \\
\text { of functional } \\
\text { significance } \\
\text { in \% }\end{array}$ \\
\hline Media relations & 10.0 & 12.0 & 14.2 & 9.1 & 9.1 \\
\hline Public relations & 17.5 & 17.9 & 12.9 & 10.4 & 8.3 \\
\hline $\begin{array}{l}\text { Crisis } \\
\text { communication } \\
\text { programmes }\end{array}$ & 9.6 & 15.0 & 14.1 & 11.3 & 7.9 \\
\hline $\begin{array}{l}\text { Corporate image } \\
\text { research }\end{array}$ & 18.4 & 14.6 & 15.0 & 9.2 & 7.1 \\
\hline $\begin{array}{l}\text { Research on } \\
\text { reputation and } \\
\text { prestige }\end{array}$ & 18.3 & 15.8 & 13.3 & 9.6 & 8.8 \\
\hline CSR & 8.8 & 11.2 & 12.5 & & \\
\hline $\begin{array}{l}\text { Internal employer } \\
\text { branding }\end{array}$ & 8.3 & 12.9 & 13.3 & 10.4 & \\
\hline Merchandising & 9.5 & 10.0 & 9.5 & 11.3 & 5.3 \\
\hline
\end{tabular}

Source: own elaboration based on a completed research project.

The consequence of properly implemented internal communication activities is a proper understanding of the tasks to be performed by employees and a related increase in productivity and quality of work. It also results in better integration among members of the organisation and allows them to express their own opinions. However, one of the most important benefits is that well-informed employees naturally become credible spokespersons for the organisation in relation to its external environment and positively influence the company's image. Referring to the above analyses, it is puzzling that there is such a large number of surveyed enterprises in which the above-mentioned internal communication activities do not occur at all. Figure 2 shows the percentage of companies in which individual activities are not implemented as part of internal communication. 


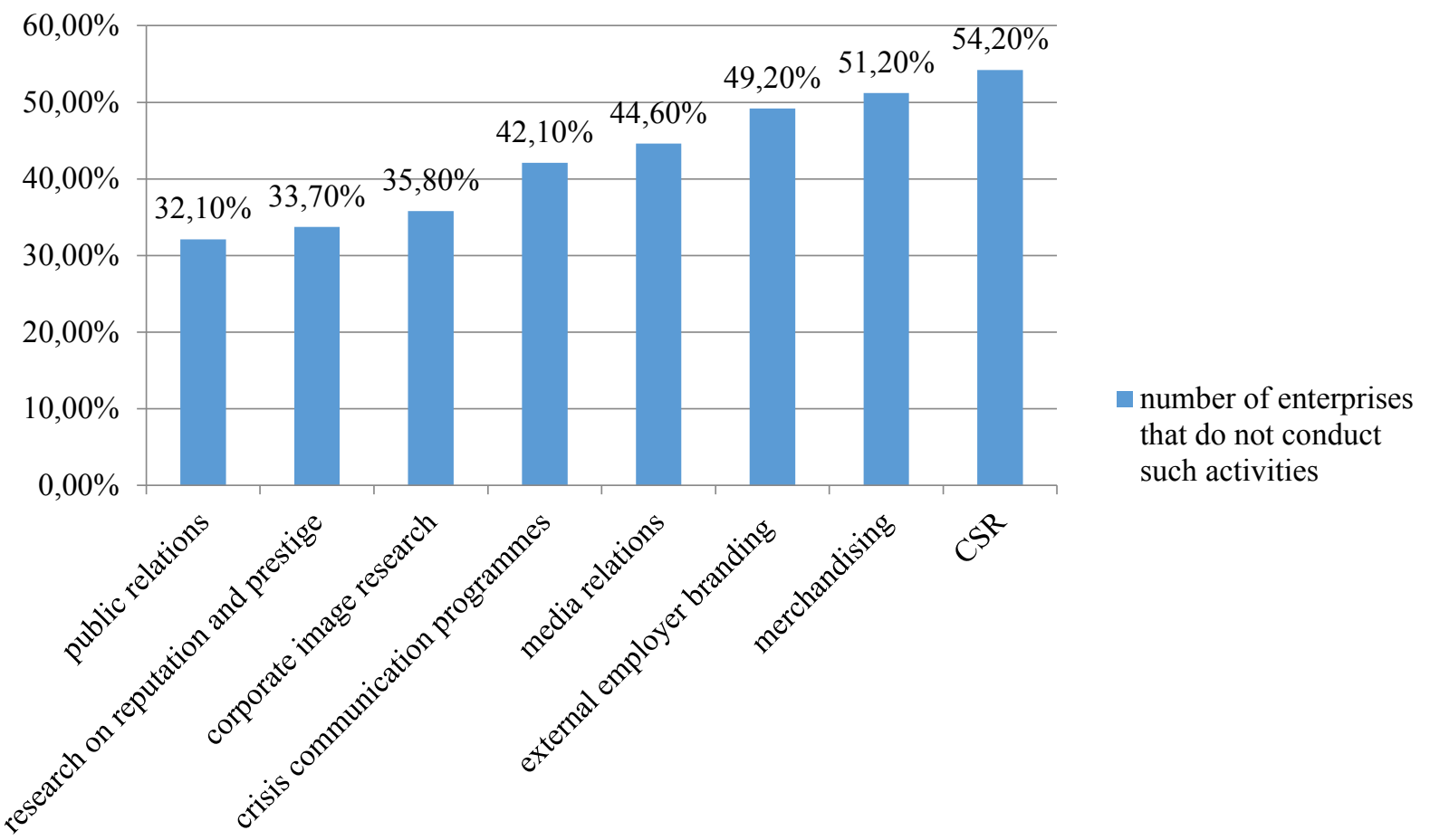

Figure 2. Number of companies without internal communication activities. Source: own elaboration based on a completed research project.

The largest number of enterprises participating in the survey do not implement a CSR strategy and merchandising as part of their internal communication, this is $54.2 \%$ and $51.2 \%$ of companies respectively. The smallest percentage of enterprises are organisations that do not feel the need to carry out activities such as public relations $(32.1 \%)$ and reputation and prestige research $(33.7 \%)$.

External communication in the organization has an equally important role as internal communication. It should be emphasized that the way in which the company communicates with the environment has a decisive impact on shaping its image. It shows the values of the company, shows its intentions, presents goals and ideas. The purpose of the company's communication is to interact with the environment. It is both the transfer of information outside, as well as receiving and analysing feedback about the company or its products. When analysing the activities that enterprises did not implement as part of internal communication, it should be noted that similar answers were given also in the context of external communication. Figure 3 shows the percentage of the number of enterprises in which individual activities are not implemented as part of external communication. 


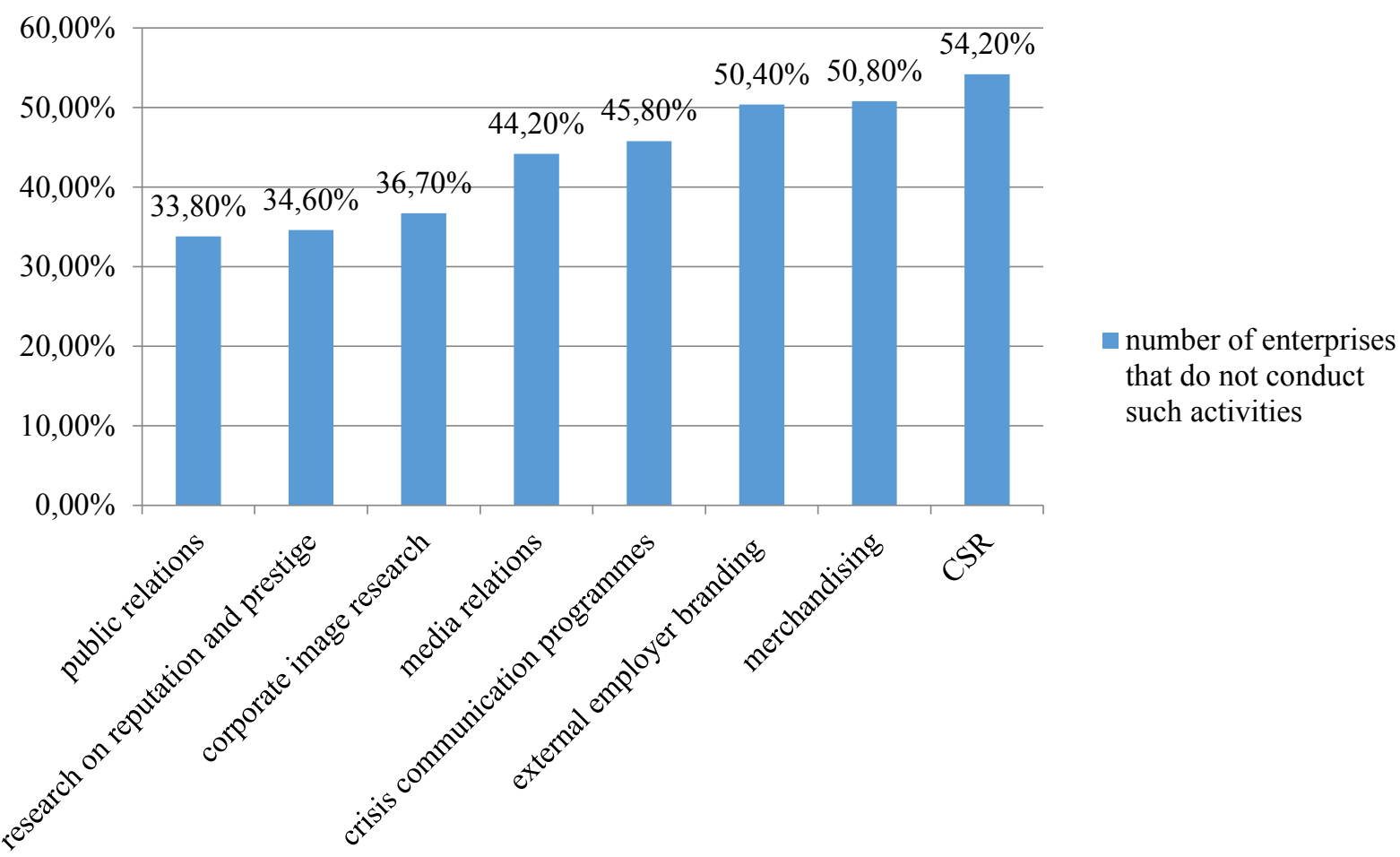

Figure 3. Number of enterprises where no activities in the field of external communication are conducted. Source: own elaboration based on a completed research project.

It turns out that more than half of the entities surveyed do not consider it important to inform external stakeholder groups about CSR strategies or merchandising. However, reputation and prestige research and public relations are activities that only one third of the surveyed companies do not undertake. It is very worrying that so many companies are still not aware of the fact that their success in the economic sphere is conditioned also by some kind of social acceptance. That is why proper communication between companies and their closer and further environment is such an important issue nowadays. It is worth emphasising that the lack of communication is also a kind of message to the environment, which carries the message that a given organisation does not care about the opinion of its recipients. There is no doubt that every company that wants to operate efficiently on the market and also intends to achieve its strategic objectives should devote a lot of energy to creating proper relations with its environment. The very manner of communication will have a decisive influence on the formation of the company's image.

Table 2 presents the percentage of respondents that define internal communication activities as strategic, operational and functional. 
Table 2.

External communication activities

\begin{tabular}{|l|c|c|c|c|c|}
\hline $\begin{array}{c}\text { Internal } \\
\text { communication } \\
\text { activities }\end{array}$ & $\begin{array}{c}\text { Very important } \\
\text { of strategic } \\
\text { importance } \\
\text { in \% }\end{array}$ & $\begin{array}{c}\text { Important of } \\
\text { strategic } \\
\text { importance } \\
\text { in \% }\end{array}$ & $\begin{array}{c}\text { Very } \\
\text { important of } \\
\text { operational } \\
\text { significance } \\
\text { in \% }\end{array}$ & $\begin{array}{c}\text { Important of } \\
\text { operational } \\
\text { significance } \\
\text { in \% }\end{array}$ & $\begin{array}{c}\text { Very important } \\
\text { of functional } \\
\text { significance } \\
\text { in \% }\end{array}$ \\
\hline Media relations & 11.3 & 15.0 & 11.7 & 12.5 & 5.4 \\
\hline Public relations & 17.5 & 17.1 & 12.5 & 9.1 & 10.0 \\
\hline $\begin{array}{l}\text { Crisis } \\
\text { communication } \\
\text { programmes }\end{array}$ & 12.1 & 8.3 & 15.4 & 9.6 & 8.8 \\
\hline $\begin{array}{l}\text { Research on } \\
\text { corporate image }\end{array}$ & 18.3 & 15.8 & 12.5 & 8.8 & 7.9 \\
\hline $\begin{array}{l}\text { Research on } \\
\text { reputation and } \\
\text { prestige }\end{array}$ & 18.3 & 15.8 & 13.8 & 6.6 & 10.8 \\
\hline CSR & 8.3 & 9.6 & 14.2 & 5.8 & \\
\hline $\begin{array}{l}\text { Internal employer } \\
\text { branding }\end{array}$ & 9.2 & 10.0 & 14.6 & 8.3 & 6.7 \\
\hline Merchandising & 8.0 & 12.9 & 12.1 & 10.4 & \\
\hline
\end{tabular}

Source: own elaboration based on a completed research project.

While analysing data presented in Figure 3 and Table 2, it should be noted that half of the surveyed companies declared that such activities as CSR, employer branding, or merchandising do not occur in their organisations. Also, a large group of the surveyed (about 40\%) declared the lack of crisis communication activities both inside and outside their organisations. This means that despite the low communication activity of the surveyed organisations, internal crisis communication activities are undertaken to various degrees by $57.9 \%$ of respondents, and external by $54.1 \%$ of respondents.

Of the group active in the area of internal crisis communication, $24.6 \%$ consider these activities important and very important of strategic importance, while $20.4 \%$ consider them important and very important of strategic importance externally.

It may be assumed that these companies are preparing for crisis communication in the future, creating the so-called 'communication plans' in case of various (probable) crisis situations.

More than $60 \%$ of the surveyed companies declared that they conduct communication activities of a public relations type: in the internal area $-68 \%$, in the external area $-66.2 \%$. Very important and important of strategic importance are $35.4 \%$ in the internal area and $34.6 \%$ in the external area.

The above result is correlated with the data on the organisation image survey and the reputation and prestige survey. Involvement in communication activities at the strategic level of the surveyed organisations is presented in Table 3. 
Table 3.

Public relations of the surveyed organisations (strategic level)

\begin{tabular}{|l|c|c|}
\hline & Internal in \% & External in \% \\
\hline Public Relations & 35.4 & 34.6 \\
\hline Researching image & 33.0 & 34.1 \\
\hline Researching reputation & 34.1 & 34.1 \\
\hline Media Relations & 22.0 & 26.3 \\
\hline Employer branding & 21.2 & 19.2 \\
\hline Crisis relations & 24.6 & 20.4 \\
\hline
\end{tabular}

Source: own elaboration based on a completed research project.

Although the surveyed organisations declared the above activities as important and very important at the level of company strategy, the results of Table 3 show that strategic activities cannot be developed without engaging in all internal and external areas. It can be considered that a group of $10-15 \%$ of the surveyed organisations declare such activities, but the level of these activities does not correspond to the strategic ones.

\section{The relationship between the level of process maturity and the organisation's activity in the area of communication}

The CMMI organisational process maturity model (Bitkowska, et al., 2011, p. 64) was used to assess to what extent the surveyed companies demonstrate process maturity in the most important business priority, which is creating value for the organisation's internal and external customers. This model provides five levels of maturity.

Table 4.

Five levels of business maturity

\begin{tabular}{|c|c|}
\hline Level & Characteristics \\
\hline Level I & $\begin{array}{l}\text { - } \quad \text { random, disorganized, often chaotic processes } \\
\text { - } \quad \text { lack of process awareness }\end{array}$ \\
\hline Level II & $\begin{array}{ll}\text { - } & \text { partially organized, repetitive processes } \\
\text { - } & \text { no description of processes, no measures } \\
\text { - } & \text { process awareness appears }\end{array}$ \\
\hline Level III & $\begin{array}{l}\text { - } \quad \text { organized, identified but not measurable processes } \\
\text { - full awareness of the existence of processes appears in the organization }\end{array}$ \\
\hline Level IV & $\begin{array}{l}\text { - } \quad \text { the measurement and process system is defined } \\
\text { - information is translated into management decisions } \\
\text { - } \quad \text { all processes are identified } \\
\text { - } \quad \text { process owners exist }\end{array}$ \\
\hline Level V & $\begin{array}{l}\text { - } \quad \text { the organization is aware of the processes taking place in it } \\
\text { - } \quad \text { strategic goals relate to individual processes } \\
\text { - } \quad \text { processes are constantly improved }\end{array}$ \\
\hline
\end{tabular}

Adopted from: "The State of Business Process Management" by C. Wolf and P. Horman. Copyright 2011 by Difin.

A detailed analysis of the surveyed companies in terms of their process maturity has been presented by the authors in a separate work (Tylżanowski, 2020, pp. 45-50). 
Whether the organization has strategically achieved an integrated state of internal and external communication, or functions in the organization's social communication system based on constructive dialogue, is determined by the number of various processes, the level of communication and the level of their process maturity. These are processes such as internal and external media relations, external and internal crisis relations, external and internal employer relations, internal and external image research, internal and external reputation and prestige research, CSR, merchandising.

Table 5.

The impact of building relationships on the formation of process maturity of the organization

\begin{tabular}{|l|c|c|c|c|c|c|c|c|c|c|}
\hline & \multicolumn{4}{|c|}{ Building internal relations } & \multicolumn{5}{|c|}{ Building external relations } \\
\hline $\begin{array}{l}\text { Companies } \\
\text { considering } \\
\text { themselves as } \\
\text { non-processing } \\
\text { organisations }\end{array}$ & 5 & 4 & 3 & 2 & 1 & 5 & 4 & 3 & 2 & 1 \\
\hline $\begin{array}{l}\text { Companies } \\
\text { considering } \\
\text { themselves as } \\
\text { processing } \\
\text { organisations }\end{array}$ & 5 & $32 \%$ & $23.8 \%$ & $6.5 \%$ & $4.1 \%$ & $25.4 \%$ & $32 \%$ & $27.9 \%$ & $9.8 \%$ & $4.9 \%$ \\
\cline { 2 - 12 } & $18.7 \%$ & $39.8 \%$ & $28.8 \%$ & $10.2 \%$ & $2.5 \%$ & $34.8 \%$ & $44.1 \%$ & $14.4 \%$ & $5.9 \%$ & $0.8 \%$ \\
\hline
\end{tabular}

Source: own elaboration based on a completed research project.

A very important aspect affecting the creation of process maturity is the building of relationships, both internal and external. Among all the companies surveyed, less than $51 \%$ of the respondents emphasise that their organisation is not considered to be process-oriented. Analysing the results in Table 5, a certain trend can be observed. Namely, organisations that do not consider themselves process-oriented believe that building relationships both internally and externally affects the creation of process maturity of the organisation in a very similar way. Meanwhile, process organizations clearly emphasize the power of positive influence on the creation of process maturity located on the side of external relations.

Achieving more and more process maturity through process improvement should be treated as a cyclical activity, which is oriented towards the continuous search for better solutions. There is no doubt that organisations that intend to improve their processes, and thus gain greater process maturity, should continually take care to shape open communication, both within the company and in the external environment.

\section{Conclusion}

The conducted research is the first step in assessing the relations that occur between the level of process maturity of an organisation and the level of communication activity. In the surveyed organisations there is a high awareness of the need and importance of processes. 
Many of them are structured processes, but not all of them are measurable. Some processes are characterised by randomness.

A positive conclusion is the study of corporate image and the study of reputation and prestige in the area of internal communication activity. A group of about $64 \%$ of organisations declared such activity, although to varying degrees. About $33 \%$ of respondents declared these activities as strategic. It should be assumed that they are the result of image activities, activities focused on reputation and prestige. It can be assumed that these are activities of public relations or corporate communication. Admittedly, further research reveals the lack of certain processes, which are important and determine the strategic character of these activities (e.g., lack of CSR, lack of employer branding). However, a group of about $10 \%$ of the surveyed organisations are certainly organisations reaching Level IV of process maturity. The remaining organisations are at Levels II and III of process maturity according to the CMMI model.

\section{References}

1. Bitkowska, H., Kolterman, K., Wójcik, G., Wójcik, K. (2011). Zarzq̨dzanie procesami w przedsiębiorstwie. Warszawa: Difin.

2. Cornelissen, J. (2012). Komunikacja korporacyjna. Przewodnik po teorii i praktyce. Warszawa: Oficyna a Woltares Kluwer business.

3. Daszkiewicz, M., Wrona, S. (2014). Kreowanie marki korporacyjnej. Warszawa: Difin.

4. Grajewski, P. (2003). Koncepcja struktury organizacji procesowej. Toruń: „Dom Organizatora”, TNOiK - Stowarzyszenie Wyższej Użyteczności.

5. Kotler, Ph. (2017). Marketing 4.0. Warszawa: mtbiznes.

6. Kuraszko, I. (2010). Nowa komunikacja społeczna wyzwaniem odpowiedzialnego biznesu. Warszawa: Difin.

7. Wojcik, K. (2015). Public relations. Wiarygodny dialog z otoczeniem. Warszawa: Oficyna a Woltares Kluwer business.

8. Tylżanowski, R. (ed.) (2020). Zarządzanie innowacjami w przedsiębiorstwie. Aktualności badawcze. Toruń: „Dom Organizatora”, TNOiK - Stowarzyszenie Wyższej Użyteczności. 